\title{
A empresa sustentável
}

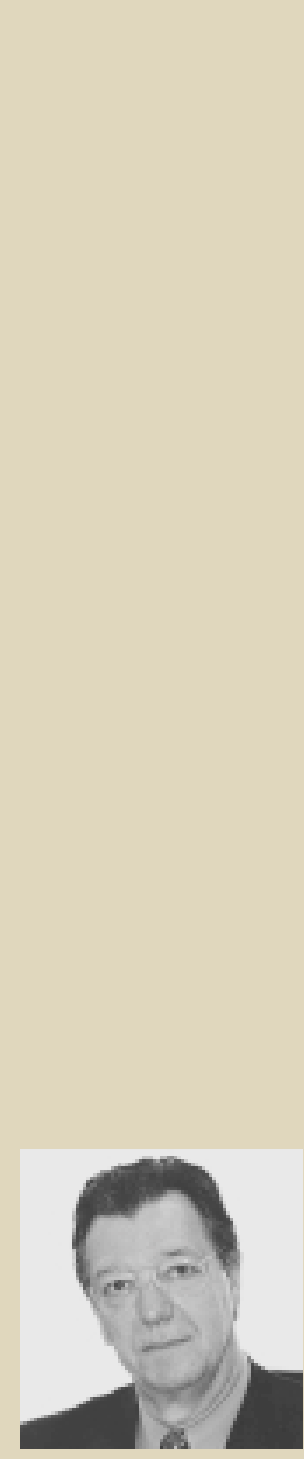

Carlos Osmar Bertero FGV-EAESP
A empresa contemporânea existe desde a Segunda Revolução Industrial . Refiro-me à empresa como entidade que existe por tempo indeterminado e que, em princípio, deve buscar a permanência. É verdade que as primeiras sociedades por ações datam do século XVI, mas não buscavam se manter por tempo indeterminado. Eram arranjos que contemplavam a realização de um negócio. Quando este se concluía, as perdas ou os lucros eram partilhados entre os investidores (acionistas) e a organização era liquidada. Diferentemente, a partir da Segunda Revolução Industrial, a empresa surge com a expectativa de se manter indefinidamente, ou seja, de ser sustentável.

A questão da sustentabilidade está mais presente em nossas vidas do que imaginamos. Dois exemplos comuns: fala-se hoje em crescimento econômico sustentável, que seja constante ao longo do tempo e que não seja apenas uma episódica seqüência de "bolhas" que se desfazem com a queda em vales de recessão. A consciência ecológica também lançou mão da sustentabilidade. Não é possível viver no planeta e destruí-lo sistematicamente. É necessário que desenvolvamos modos de vida e formas de convivência com o ambiente que assegurem a presença sustentável do ser humano na Terra.

A questão da sustentabilidade da empresa não deixa de ser dramática. Dados sobre micro, pequena e média empresas demonstram que suas vidas são curtíssimas. 0 cenário atual mostra que o fenômeno atinge também as grandes empresas. Muitas fusões e aquisições podem ser eufemismos que ocultam o fracasso de algumas empresas que, afinal, são absorvidas por outras de melhor sorte e desempenho.

Da perspectiva da gestão estratégica, podemos propor a sustentabilidade como a principal meta a ser perseguida pelos administradores. $\mathrm{Na}$ verdade, empresas perdem sustentação por diversas razões. 0 ciclo de vida de produtos e serviços é um ponto. Para que a empresa permaneça, é necessário que o portfolio seja constantemente renovado. Outros pontos de sustentabilidade devem ser explorados, como a interface com os acionistas. É necessário também estar atento à volatilidade das tecnologias e de clientes.

Nada pode servir melhor como força propulsora à gestão de uma empresa do que procurar torná-la sustentável aos acionistas, clientes e fornecedores. Isso seria capaz de eliminar o imediatismo e o oportunismo que se satisfaz com sucessos de grande intensidade e pouca duração. Em um mundo onde as ações presentes acabam hipotecando e comprometendo o futuro em diversas áreas, como na ecologia ou com o crescente endividamento público e empresarial, a sustentabilidade seria um conceito e uma meta a merecer maior reflexão e aplicação prática. 